\title{
Discovering the Colonial Discourse in Lawrence in/of Arabia: A Postcolonial Reading
}

\author{
Safa Almijbilee \\ Baghdad, Iraq
}

\begin{abstract}
Middle Easterners and Arabs are frequently depicted as backward, inferior, and primitive in Western literature and media. One of the works which focuses on the lives of the Arabs is the novel Lawrence in Arabia (2013) by Scott Anderson. Although the author has spent some time in the region that he has depicted, his descriptions consist of stereotypical generalizations about the Arabs. Hence, this study tries to investigate the partial intentions of the author throughout his novel. Moreover, the influences of media and Western sources about the Arabs' lives in his work are traced. To support its claims, the thesis sheds light on the discourse of the novel with the help of Foucault's definition of "Discourse", Said's "Orientalism", and Bhabha's "Stereotype". These concepts help this study display how the novel presents the Arabs as exploited, marginalized, inferior, and in need of control in every aspect of their lives (i.e. cultural, social, economic, and political). Also, it is discussed how the author, as a colonizer, stereotypes the colonized in his text. In addition, the study tries to find the same trend in Lean's movie, Lawrence of Arabia (1962) and show how it influences Anderson's view on representing the Arabs. Consequently, the findings prove that Anderson is influenced by the Western sources in his writing and media has a significant role in transferring a degrading picture of the Arab to its audience.
\end{abstract}

Keywords: Discourse, Orientalism, Other, Middle East, Stereotype, Postcolonialism, Scott Anderson's Lawrence in Arabia (2013), David Lean's Lawrence of Arabia (1962).

DOI: $10.7176 / \mathrm{JEP} / 10-15-10$

Publication date:May $31^{\text {st }} 2019$

\subsection{Introduction}

Lawrence in Arabia (2013) recounts the tale of Thomas Edward Lawrence (1888-1935) or as he is better known, the "Lawrence of Arabia". He remains one of the most paradoxical figures of the twentieth century. T.E. Lawrence was a British agent and the general who led the Arab Revolt. Although the revolt was initiated by Sharif Hussein bin Ali in Mecca as an independence movement aiming at dethroning the Turkish dynasty, The British and the French (the Allies) supported the Arab Revolt (1916-1918) and used the victory for their own interest.

This chapter strives to shed light on the novel from postcolonial perspectives. Discursive colonial authority, subjection, and the postcolonial theories of Bhabha and Said and their innovative ideas about Foucault's work are going to be analyzed throughout the novel. In developing these arguments, the chapter examines a postcolonial text that represents the Other and the marginalized Arabs. The colonizers who see themselves as superior and the colonized who are seen as inferior live side by side and deal with each other. There is a social and cultural interaction between the two sides: the colonizer versus the colonized, or the East versus the West. The West and the Arabs are both encouraged to view the imperialistic relationship as beneficial for everyone.

Underscoring the colonizer's influences in the Middle East, this chapter with the help of colonial discourse, Orientalism, and stereotype tries to investigate the novel about Lawrence, written by an American writer, to show how the colonizer exploits the colonized, i.e. the Arabs in the Middle East. In doing so, the study starts from Edwards Said and his idea of stereotype to examine and explore the stereotypical images of the Arabs depicted by the Westerners and the writer, Anderson, in particular. Mostly, these images are the negative images, describing Arabs as primitive or irrational. Then, the dignified images of the colonized will be probed in the same novel. In the next section, the focus will be on Bhabha's elements of mimicry and hybridity from both sides, the West and the East. Whether the colonizer or the colonized is affected more by these phenomena is discussed in this chapter.

\subsection{Edward Said's Stereotyped Image of the Arabs in the Novel}

Colonialism refers to the historical processes in which some countries build empires through controlling some weaker countries, the colonized. One of the major effects of colonization is the cultural conflicts represented in the interaction between the Arabs and the Western colonizers. An extreme reaction to such clashes will lead to stereotyping the inferiors and accordingly justifications are made for these degrading attempts by the people who initiate them. The gap created between the West and the East is the result of not accepting each other's cultural varieties and trying to represent one's superiority to the other. As mentioned by Anderson (2013):

The mashed-together cultures of Europe and the Middle East of the early twentieth century, where faith and ethnicity and nationalism were all exerting tremendous and often opposing pulls, just whose claim to self-determination was to win out over others? (p. 1013)

The West has endeavored insistently to show the East as the inferior. The most eminent endurance of Western 
colonization, expansion, and domination over the East is depicted in the writing (Adas, 2010, p. 371). Therefore, studies of postcolonialism and colonial discourse studies criticize the neglected cultural differences, when the West focuses on the Western representations of the East and in the case of this chapter, indigenous Arabs. The process of stereotyping includes both creating positive images of the colonizers and negative, degrading images of the colonized (Said, 1978, pp. 152-153). In the next section of the thesis, both these images are going to be discussed in the novel under study, Lawrence in Arabia (2013). Since in colonial and postcolonial discourses, the superiority of the West is usually established and proved by the inferiority of the colonized, first, the study will focus on the colonized and its stereotypical images in the text.

\subsubsection{Degrading Images of the Arabs}

Middle Easterners have experienced several usurpations in the last five decades: dictatorships, civil wars, religious extremism, terrorism, genocide of ethnic minorities, and four major American military invasions (Anghie, 2007, p. 211). Anghie (2007) suggests that these incidents are the result of the political and economic exploitation done by the West and can be justified by international laws as a Civilizing mission (p. 211).

Arab's culture and representations have been greatly affected by the binary oppositions created by the colonizer between the powerless East and the powerful West. Occupying a much more powerful position than the Arabs', Western imperialism delineates and writes about the region of the colonized instead of its settlers. Hence, this allows the colonizer to manipulate historical facts for his benefit.

Through controlling the East and their minds, the West furthers its plans on imperialism (Sium, et al., 2012, p. 7). Colonial knowledge has enabled the colonizers to rule and divide the country constantly; as it is mentioned in the book, "Sykes had other cards to play. Chief among them was his ability to control the flow of information" (Anderson, 2013, p. 646). One of the measures taken by the colonizer is creating a border between the colonizer and the colonized and categorizing cultural norms in colonized societies as backward and in need of improvement. Anderson also believes in the inferiority of the Arabs; it is manifested in the following statement; "culture and savagery, I have lived among them all my life and it would be difficult to sway me from my opinion that there is no more cowardly, hypocritical, and false race than this one" (Anderson, 2013, p. 286). Through different social, cultural, political, and economic institutions, the Colonizer establishes its superiority (Memmi, 1974, p. 70).

One of the main issues of the novel as well as the film is in the representation of the characters. How the leaders of the Arabs, such as King Hussein and King Faisal, are not fit in taking positions of power is shown in the novel. The following excerpt from the novel describes Faisal's fault in leading the country:

By going into partnership with the Zionists under such circumstances, Faisal had just handed his more conservative Arab and Muslim rivals a powerful weapon to use against him. One who would soon wield that weapon to devastating effect was King Hussein's chief rival in Arabia, ibn-Saud, and his fundamentalist Wahhabist followers. (Anderson, 2013, p. 1016)

Humiliating the Arabs can stem from the system of law and Western thought which suggests that the colonized people cannot govern their countries without the help of Western powers. "Neither Sykes nor Picot believed the Arabs were truly capable of governing themselves, they could pledge independence for these enclaves secure in the knowledge that they would end up as British and French vassal states" (Anderson, 2013, p. 344).

As the Arabs are weakened, the exploiters gain more power to control them. Depicting the Arabs in a lower status is one of the strategies that the colonizer adopts. The excerpt below shows Colonialist narratives which depict the East as backward and simple minded while the West represented by Syke's is progressive:

Sykes's special skill in this regard was a talent for bold and refreshingly concise writing, the ability to break down complex issues into neat bulleted-point formulas that provided the illusion of almost mathematical simplicity. He was a master of the PowerPoint presentation nearly a century before it existed (Anderson, 2013, p. 436)

Also, despite direct and indirect references to the Arabs' lack of leadership skills, the colonial discourse tries to directly create negative, subservient images of the colonized in order to fulfill its mission. On several occasions, in the book, the Arabs are associated with negative features; one of them is being thieves and in need of protection from each other (Ridouani, 2011, p. 8). The excerpt bellow suggests how the book shows the Arabs as heartless and merciless:

The whole place was indescribably filthy, defiled and littered with smoldering cinders and the soiled leavings of loot. Turks, some dead and some dying, lay about the railway station or sat propped against the houses. Those still living gazed at us with eyes that begged for a little of the mercy which it was hopeless for them to ask of the Arabs. (Anderson, 2013, p. 985)

One of the strategies to control the colonized is to marginalize them financially and politically. The lack or absence of development and progress in the colonized country leads to its economic stagnation; hence, the colonizer buys its raw material instead of its own and uses it to improve the industries and expand its control over the colonized. (Memmi, 1974, p. 173)

The Colonizer argues that the colonized society is a diseased society where the natives are unable to succeed in creating a new system or government (Memmi, 1974, p. 155). In this book, it is mentioned during the 
colonization and division of the Arabs among the Western powers:

whoever takes over Syria ought to realize that to have a purely native administration running things badly, but with prospects of improvement, represents more real progress than having a European staff doing things properly, but [with] the natives learning nothing. (Anderson, 2013, p. 1033)

Hence, the West by associating the East with inferiority tries to create a new East with new systems of government, education and socioeconomy which will be beneficiary to its interests (Memmi, 1974, p. 25).

Up to now, we have discussed the different instances of the Arabs' degradation through some issues such as leadership skills, war strategies, and ethical values (being merciless); yet, there is one more realm to which the colonizer has resorted in order to humiliate the colonized: the matter of language. Said (1978) argues that the Orient is not taken seriously as a whole but as fragments, since the Orient cannot be considered worthy without his or her mediation (p. 129). Providing instances in his book from the representation of the Orient in lower status, Said (1978) quotes the Occident, commenting that "the Arabic language is much given to rhetoric, Arabs are consequently incapable of true thought" (p. 316); thus, Said critically asserts "that it is because there is an intrinsic weakness in the Arabic language itself that Arabs become unable to produce any great art and are unlikely to do so in the near future" (Muharram, 2012, p. 140).

This is also manifested in the novel, while Arabic language is used by Anderson merely as a tool for attracting the trust of the Arabs and manipulating them (Anderson, 2013, p. 888). Or when they refer to its incompetency because of the different spelling and meaning that an Arabic name has:

For example, a man named Mohammed al-Faroki, whose surname appeared in different documents of the time also as Faruqi, Farogi, Farookee, Faroukhi, etc., will appear as Faroki throughout. The most notable case in point is that of T. E. Lawrence's chief Arab ally, Faisal ibn Hussein, usually referred to as Feisal by Lawrence, but as Faisal by most others, including historians. To avoid confusion, I've changed all spellings to the latter. (Anderson, 2013, p. 13)

The different degrading images of the Arabs found in the novel were discussed and elaborated in the previous section. However, the dignified images of the Westerners are also present in Lawrence in Arabia (2013). This is going to be the focus of the following part of the study.

\subsubsection{Dignified Images of the Westerners}

Just as the colonized is depicted as weak and subservient in different regards, sometimes, the colonizer is referred to as the source of power to which the colonized can resort. Moreover, as already mentioned, they are represented and portrayed by the West as the second class, while a Western leader such as Lawrence is described as "a natural leader of men" (Anderson, 2013, p.19). This is because the West needed access to serve their own ends, encouraged certain Arabs to rebel by giving them fake promises and false hopes. "The [Sykes-Picot] agreement was a device for bringing about an Arab revolt to suit the designs of the British" (Anderson, 2013, p. 844). Anderson focuses on Westerners and their meddling to manifest the damages prevented by the Western interference; the cultural and moral mission of the colonizer is simply a direction towards an easier life, an area where one earns more and spends less. Lawrence, the mouth piece of the invaders, says:

[The Arab revolt] was always something of a mirage, the differences between its radically varied cultures far greater than what united them... and advances in technology and communication would almost certainly have soon brought these disparate cultures and peoples into conflict. (Anderson, 2013, p. 1023)

Lawrence has the ability to influence and personify many roles in the Middle East during his journey for the side of the British front: “[. . .] but it reflected just how powerful Lawrence had become: he was his nation's vital link to the Arab rebels in the field, no one else could fulfill that role, and because of this, he could say or do nearly anything he wished." (Anderson, 2013, p. 890).

Arab's weakness in war strategies is manifested in another point of Lawrence's tale. Allying with the Arabs against the Turks, Lawrence uses military strategies to help them win. Anderson elaborates on the war strategy at the time, as mentioned in the following excerpt:

Medieval military history - and warfare in early-twentieth-century Arabia bore striking similarities to that in fourteenth-century Europe. These similarities extended from how a fighting force was recruited, to its leadership structure - trade out sheikhs and emirs for lords and thanes and princes - to how that fighting force maneuvered in the field. (Anderson, 2013, p. 436)

This idea is reinforced in another part of the novel, when he justifies his claim by associating Lawrence's leadership skills with his European origins: "Lawrence soon came to be something akin to a construction foreman. In this role he discovered, perhaps as much to his surprise as anyone else's, that he was a natural leader of men. ... To be sure, this was partly due to his status as a European" (Anderson, 2013, p. 75). Based on the excerpt, it is revealed that T.E Lawrence was aware of medieval military strategies, so he helped the Arabs in the battlefield. This suggests that the East could not succeed without T.E Lawrence's war techniques (figure 4).

The other issue in regard to the West's superiority over the Arabs is expressed in the matter of government. These are the colonizers who teach the Arabs how to govern their country. One of the most recent colonizations is the invasion of Iraq in 2003. The "United States denies imperial ambitions because, it claims, it is not intent on 
colonizing the Iraqi people but rather, on restoring their sovereignty by guiding them towards self-government" (Anghie, 2007, p. 280). The colonizer offers his exploitations as services to the colonized. The colonizer claims that the Iraqi self-government and protection to Iraqi people is the results of its war on terrorism in the Middle East. Thus, the occupation of Iraq by the United States is disguised behind its imperial economical interest. Besides declaring its importance to the existence of the colonized, the colonizer devalues the government of the colonized by calling it weak (Anghie, 2007, p. 280).

At times in the novel, Anderson excludes the Arabs' opinions and bolds the racist assumptions about the Arabs and other colonized people. This is another way of bolding the colonizer and marginalizing the colonized: "The only pity is the sweat to work [the Arabs] up, and the wild scramble while it lasts. It's the most amateurish, Buffalo-Billy sort of performance, and the only people who do it well are the Bedouin." (Anderson, 2013, p. 770). The dominant ideologies underlying the foundation of literature and culture suggest that the West is civilized and superior in power. According to Anderson (2013), there is "an emphasis on charting the confluence of Eastern and Western cultures" (p. 51).

And the next issue that is used to show the superiority of the Westerners is the matter of language and discourse. The term discourse is used in literary texts and it was developed by the French philosopher, Michel Foucault. Discourse has different functional definitions which vary from one usage to the other. The definition of the word used in this study is the human speech in action. Thus, the language is considered as a system of signs and an instrument of communication, whose expression is discourse (Benveniste, 1971, p. 226). People interact through language; so the implementation of power as a means of interaction can be found in the language they use.

Therefore, language is a weapon to gain power; the colonizer had adopted the soothing language of conciliation whenever the future of political framework was at stake (Anderson, 2013, p. 745). Foucault's notions on discourse and power regards that the roles of language/discourse/texts is a hierarchy of relations and they are associated with power relations (Ifversen, 2003, p. 8). According to Foucault, beliefs, whether false or true, can be fostered through language and affect people's lives since discourses include the production of texts which makes objects and events appear real/existing and not mere groupings of utterances (Mills, 2003, p. 51).

Colonial discourse, as one type of discourse, encapsulates a set of rules in investigating the specific ideologies underlying the texts (Mills, 2003, p. 95). Mills (2003) echoes Said's Orientalism (1978), when he mentions that Colonial texts are steeped in a particular world view that originated from the belief that native populations are inferior to the colonizer. Such a notion is reflected in the novel. Anderson (2013) mentions that "The upside-down worldview that this war against its military and cultural inferiors had induced in the British high command" (p. 360). Such a pattern in discourse can be found in Lawrence in Arabia (2013).

The novel begins with this sentence "In war, language itself often becomes a weapon" (Anderson, 2013, p. 11). Lawrence's tale is narrated by the colonizer and most of the documented credit is given to the West as the winner of the revolt. On the other hand, Lawrence is described as an influential figure because of his skills in using language and interacting. He has diplomatic skills and his ability to connect cultural and political gaps between the British and the Arabs is remarkable (Alkabani, 2016, p. 2). Scott Anderson refers to the issue, revealing that "Eurocentric perspective ..., in its most pernicious form, serves to validate the European view of history" (Anderson, 2013, p. 12). The different discourses or discursive structures allow the West to take over the power. Power is captured from others and can be possessed or held at another's expense. The West has the right to circulate discourse and justifies it by claiming that the texts are demolished or hidden (Merten and Krämer, 2016, p. 252). Now, having all these in mind, the thesis turns to Bhaba's ideas on mimicry and hybridity and tries to bring evidence from the novel.

\subsection{Homi Bhabha, Mimicry, and Hybridity in the Novel}

Homi Bhabha (1983) and his ideas on mimicry and hybridity will be discussed in this section. Both the colonizer and the colonized, by being under the influence of the other culture, experience mimicry. Mimicry includes the imitation of language, dress codes, politics, and cultural attitude of the opposite culture.

The other concept proposed by Bhabha (1983) is hybridity. It is a process that "causes the dominant discourse to split along the axis of its power to be representative, authoritative" (Bhabha, 1994, p. 113). The colonized, as suggested by Bhabha (1983), under social and cultural pressures, accepts the alternative attitude and identity presented by the colonizer (p. 18). This process is called hybridity in which Eastern and Western cultures mixes. This type of change is applied to both the colonizer and the colonized. Since both cultures (that of the colonized and the colonizer) are affected by the processes of mimicry and hybridity, they will be probed in the novel from the two aspects: the representation of the Arabs and the Representation of the Westerners.

\subsubsection{The representation of the Arabs}

First of all, the Arabs are supposed to learn and master the western values and norms in order to be able to live a good life. This is manifested is some parts of the novel and these values turn to an inevitable task for the Arabs, who cannot manage their lives without them. The Middle East was ruled by Western power, control and political views. The dream of the Arabs taking power and controlling themselves was diminished: 
In its place, what he envisioned was a kind of political finishing school administered by the Western powers, a period in which the benighted races of the Middle East might be instructed in Western values and systems and then sent on their merry way. (Anderson, 2013, p. 755)

\subsubsection{The Representation of the Westerners}

The Different traces of hybridity and mimicry can be found in different characters of the novel. The changes in the character of the colonizer are displayed in Lawrence's behavior and more evidently in his statement: "I will have such difficulty in becoming English again" (Anderson, 2013, p. 63). The elements of mimicry by the Westerners can also be traced in the behavior of Lawrence (see figure 1 in Appendix). Lawrence's use of Oriental regalia and the adoption of the iconic Arab costume marginalizes him from his countrymen, the same point that was mentioned in the previous quotation. Despite its ambivalence, the image of Lawrence as an icon of Orientalist exoticism, continued to intrigue the public. Being his own judge, Lawrence wrote an autobiography of the events of the Arab Revolt, Seven Pillars of Wisdom (2015). Lawrence is described as follows: a hybrid blond Arab/English who is wearing Arabian regalia in an attempt to disguise his ethnic background (Alkabani, 2016, pp. 2-3). Such an attitudes is evident in the excerpt below:

A tiny figure in a dirty Arab robe wandered into Clayton's office...the distracted general was in the process of shooing him out the door when he noticed the familiar lopsided grin, the piercing light blue eyes. It was T. E. Lawrence. (Anderson, 2013, p. 712)

Lawrence is one of the few historical personas to be disguised as an Orientalist while travelling in the East. His linguistic skills in speaking fluent Arabic as well as his magnificent disguise technique enabled him to earn the respect of the Arabs and their Sheiks: "Speaking Arabic fluently, traveling, living and working among the Bedouins, he has a knowledge of the sentiments and feelings of the Arab tribes" (Anderson, 2013, p. 888). Knowing the language, Lawrence becomes involved in the political and socio-economic conditions as he had the role of co-leader in the Arab Revolt. Thus, his engagement with the Arabs changes Lawrence from a passive scholar into an active general.

However, Lawrence's Eastern dress code and Arabic language are justified by his colonial intentions as the colonizer's agent. To win over the hearts of the Arabs, British Lawrence wears Arabian costume (see figure 1 in Appendix) and speaks Arabic fluently; this is described in the sentence from the novel, "by now quite fluent in Arabic. He did so by quizzing the men in his work crews, by visiting them in their homes, by taking painstaking notes on all he learned" (Anderson, 2013, p. 73). Or sometimes, the Arabic dress code was used by the character to survive some dangers as in the line of the novel: "even that Lawrence wear a headdress over his army uniform so as to cast a sufficiently Arab-looking silhouette in the moonlighto by quizzing the men 424).

During the Arab Revolt, he is represented as an Anglo-Arab who has mutual interests with the Arabs and rebels against the Turks. Thus, through representing himself as one of the Arabs who shares their interest, i.e. his Oriental camouflage, he attracts the Arabs' trust and as a result, the British can easily control them. Hence, he hides his true cunning image behind the regalia; while Faisal "was far more distrusting of the European allies than his older brothers" (Anderson, 2013, p. 450), he trusted Lawrence as a war leader.

However the change in identity cannot be prevented even for the colonizer, as Anderson mentions: "for the longer he stayed in Syria and the more he was accepted by the locals, the less Lawrence came to think and act like a Briton" (Anderson, 2013, p. 77). However, as already mentioned, the attitude of the writer is negative on the part of the colonizer and positive, on the part of the colonized since they need to learn all those traditions.

The exploitation of the East by the West happens through different institutions and tactics. The Arabs have experienced cultural conflicts over the past century due to several invasions. Although the colonized Arabs revolted against the Ottoman Turks, they are ruled by the European colonizers. Considering different cultural, social, political and economic differences, the relationship between the colonizer and the colonized is complicated. The colonizer by stereotyping the colonized people with negative qualities tries to weaken them so that he can occupy the superior position to control them and exploit their resources. However, the colonizer justifies his action. Colonizer claims that the weak and powerless colonized are in need of such powerful countries to control them. This study by analyzing the novel, Lawrence in Arabia (2013), revealed the colonizer's strategies for maintaining power, dominance and superiority over the marginalized groups. This chapter covered how the Arabs are marginalized politically, economically, socially, and culturally. For better advancement in imperialism, the West marginalizes the Arabs to control them completely. The cultural exploitation of the West occurs when they write the history for their own benefit. Lawrence's story is an example of such distortions of reality. Although Anderson tried to be impartial, his biased attitude is reflected in his colonial discourse of the novel towards the Arabs. Western media by producing cultural products, whether in the form of texts or motion pictures, can impact the audience. The next chapter will discuss the significant role of the media in general and the movie Lawrence of Arabia (1962), in particular in fostering the ideas about the Arabs as an inferior race.

\subsection{Media}

Media, a mirror for reflecting cultural conflicts, is one of the fields in which Postcolonial theory can be discussed. 
Regarding the Eurocentric assumptions of the West and its attempts in taking control of the East, this thesis sheds light on the history of mass media and its development. In doing so, a Western production about the East, that is the movie, Lawrence of Arabia (1962), will be discussed; this movie later becomes a source for writing Anderson's novel, Lawrence in Arabia (2013). Postcolonial theory can elaborate on dominant West-centric logics of history and its effects on the media.

The media tries to attract the audience and thus gain more money at the cost of distorting realities and making their tales more dramatic. In doing so, famous people are characterized as fabulous and exaggeratingly overexpressed (Wilson, 1990). When the British government had opened its secret records and files about the First World War and the Middle East, Lawrence's story included, movie makers took the chance to recreate the legend of Lawrence, mingling with the Arabs, to their own interest by employing manipulations and false representations of the reality.

This chapter of the thesis will be dedicated to exploring Said's idea on stereotyping on both the colonizer and the colonized. In this section, the different examples of such images in the movie, Lawrence of Arabia (1962), will be explained and elaborated. Just like the previous chapter, the effects of mimicry and hybridity will also be discussed in the movie. It will be shown how both sides are affected, according to Lean's movie.

\subsection{Edward Said and Stereotyping in the Movie}

Different ethnic and social groups are portrayed partially in modern communicative platforms, such as TV and more recently the Internet. Focusing on the media depictions of the Middle East and Islam, Said (1978) states that news-photographs are full of images which associate Muslims, Arabs, or jihadists, interchangeably with dread and danger, going to control the world (p. 287).

This chapter focuses on the development made from production of the movie, Lawrence of Arabia (1962), in the composition of the novel, Lawrence in Arabia (2013). Lawrence of Arabia (1962) is a four-hour historical film portraying T.E. Lawrence. David Lean, its director, is considered a highly respected and one of history's greatest film makers. It is said that Lawrence of Arabia (1962) is an epic and has left an unforgettable mark in film history and has inspired many generations (Fraiman, 2017). The film is based on a cinematographic adjustment of T.E. Lawrence's work, Seven Pillars of Wisdom (2015) (Barbudo, 2014, p. 87). It has won seven awards, including the Best Picture and Best Director. Also, it is ranked highly as the third greatest British film of all time in 1999 and the seventh in the United States in 2007 (Fraiman, 2017).

Media is classified into several broad communication enterprises such as: books, films, papers, and TV. The focus of this study is to show how discourse is portrayed in the movie, Lawrence of Arabia (1962), and the book, Lawrence in Arabia (2013). By investigating the similarities between the two products, this section tries to analyze the Western colonial tendencies of David Lean and Scott Anderson. Moreover, how the production and reproduction of stereotyping the Orient (the Arabs) can be found in both works are illustrated.

\subsubsection{Degrading Images of the Arabs}

The American writer, Scott Anderson, retold the legend of Lawrence for the twenty-first-century audience, a crowd of people who are interested in knowing about the history of the Middle East due to the recent attention of media to this region. Lawrence remains amongst the most perplexing figures of the modern time. Thus, this chapter will discuss the movie as a medium and its influence in shaping the audience's mind, in general, and Anderson's mind in particular about the people from the Middle East.

"Any communication channel used to simultaneously reach a large number of people, including TV, films, books, and the Internet" is called Media (Abdullah, 2013, p. 2). Media has powerful effects on the public. This type of communication is done via verbal and non-verbal forms and the message transmitted to the audience has significant effects on their thinking (McQuail, 1994, p. 327). The media and its messages play a significant role in affecting people's opinions; one should pay attention to the structures and strategies of these discourses and to the ways the audience of such discourses correspond with these so called authentic and reliable institutions, in this case Hollywood and especially the production of the film, Lawrence of Arabia (1962). The movie is one of the most watched films of all times. This section will show how movie as one form of media manipulates the frame of minds and the audience by offering distorted images of the Arabs and using generalizations so as to associate inferiority with the Arabs.

Media can be the best channel through which the cultural conflicts are manifested. One of the clashes between cultures for centuries has been the West versus East, in this case the Arabs. The Western media compares the two unique cultures to emphasize one's superiority over the other. The methods of presentation of the degradation have changed over time (Merten and Krämer, 2016, p. 241); however, the content of stereotypical aims still lies there. American and European media tries to portray the East as a threat to the West. Therefore, the West has the authority and legitimization to defend itself against such threats by dominating and controlling the economy and military as discussed in chapter three and media which is going to be discussed here.

Arabs' culture is associated with their religion, i.e. Islam. Western movies and series, including this movie, have tied to focus on those who are extremists and abuse the peaceful laws of Islam in order to show brutality, 
violence, and barbarism in this religion. Fundamentally, Islam emphasizes having peaceful relations with both Muslims and non-Muslims and when such peace is breached, jihad must be employed (SardarAli and Rehman, 2003, p. 2). However, the term, jihad, has been deformed since it is associated with blood, thirst, revenge, and violence. To Muslims, the holy war is a defense and protection and it does not take the form of an attack. Although on the media, it is shown that young Muslim men take to the streets to fight and die for the cause, the reasons for their jihad is protecting their country from division by the superpowers of the West.

The Arabs are constantly being portrayed in the same manner which indicates that they are defected and unrealistic. One of the issues being discussed and shown repeatedly by the Western media is their dress codes. In Western media, particularly motion pictures, the people who wear Arab costumes (scarves and veils) are associated with terrorism. By fabricating the truth about Islam and the dress code it obliges, the Western media generalizes and repeats the image which links Arabs to some discrediting acts such as terrorism. In doing so, the West can gain control and surveillance over such dangerous people (Ridouani, 2011, p. 10).

In the movie, also, the dress code is associated with savagery and violence. In the train scene, the Arabs, led by Lawrence and dressed in Arabic costumes, attacked the Turks in a very savage way (2: 28': 00"). Even the Western Lawrence is wearing an Arabic costume, attacking the Turks, in the accompaniment of the Arabs. In another scene, Lawrence, wearing Arabic clothes, is denied entrance by the Western generals. Assuming that he was an Arab, they did not let him in (2: 00': 20").

Today the United States sets a stand leaving a fingerprint on numerous postcolonial studies. These American ideologies are now accepted globally as European countries such as England and France were controlling other countries and nations in the past; today the emergence of United States is spread globally. Going, from Euro centricity towards American centricity has been the new global trend. There have been various national goals for foreign aid, including national security, national economy, and global environment. Promoting aid programs aim to justify political objectives. Some of them include: securing the country's sources of oil or extending the market for the items in which they have special interest. "The interest or benefit of Europeans and their descendants is pursued at the expense of others while justifying this worldview by paradigms or ethical norms that proclaim universal benefits for all" (Mehmet, 2014, p. 101).

The appropriate responses can be unexpected. Opinions on Lawrence frequently reflect implicit agenda on issues such as war and imperialism. However, it is confirmed that imperialism is its intension, "All is fair in love, war, and alliances, Lawrence wrote Yale in 1929" (Anderson, 2013, p. 387). This shows the imperial greed of the West, showing the need of the Arabs to win the war against the Turks: "the newest British weapon to be introduced to the Arabian front, the Rolls-Royce armored car, it was immediately apparent to all that this new weapon fundamentally changed the desert war" (Anderson, 2013, p. 863).

Moreover, giving shameful qualities to a few Arabs and associating it with the Arabs in general via media can be considered one way of stereotyping. The movie, Lawrence of Arabia (1962), depicts the Arabs through the medium of film and media. In the movie, the desert full of sand and heat is shown as the only setting (2: 28': 00") as if all the Arabs live in tents and ride camels all the time (Wilmington, 2002, p. 1). Thus, the West had been propagating the cliché pictures of the Arabs and Muslims by using the technique of generalization.

Stereotyping the Arabs as uncivilized people who live in tents is a Western propaganda which is transmitted and spread through media. Moreover, it is insinuated that the East needs to be represented by the West since they are passive and in doing so they justify their roles in managing the contents of media (Said, 1985, p. 202). By fabricating a twisted truth, media transfers cultural and racial hatred and hostile feeling towards the Arabs to the audience. The Western portrayal of the Arabs as inferior is an ongoing opinion that has been established in the West far back to the first contact with the Arabs and Muslims during the period of the crusades. Regardless of whether the contact occurred in the past hundreds of years or later, the West conceptualizes the Arabs and Muslims as outsider "Others" or rather "enemies" (Eltantawy, 2007, p. 216 and p. 336).

Such representations can be manifested on media and it will manipulate the viewers in favor of what the director and producer want to present. Foucault claims that some statements are more authorized than others (Hewett, 2004, p. 22), in that they are more associated with those in the positions of power or with powerful institutions. For instance, Western news associations, i.e. CNN and BBC, are seen as the standard news agencies, while non-Western Al-Jazeera agency is considered a media with partial news reports. The matter of language and how it is used for abusing people's minds are going to be discussed in the following section.

In the movie about Lawrence, the Arabs are always associated with holy war, terrorism, hatred, savagery, and violence as if they are all Bedouins. Western media has a tendency in showing the Arabs and Muslims as "terrorists", "erotic", "primitive", and "ignorant" among other numerous disparaging terms (Shaheen, 1984, pp. 180 and 203). By manipulating audience's mind and stating that all Arabs are uncivilized Bedouins, the negative thinking towards the Arabs is shaped and this can lead to the Western producers' benefit in advancing their exploitive interests. The powerful elite, superior West has access to the public through the media. The images that are shown in the movie are filled with savagery. In one scene, Arab soldiers tear off the clothing of Turks, and cut their throats (2: 29': 47"). There are many similar scenes, degrading the Arabs, in both the novel and the film. One 
of these scenes shows the Arabs as looters. Moreover, in the novel and the movie about Lawrence, the colonized is depicted as coward and chaotic (Memmi, 1974, p. 147).

The narrative of the script and the novel both introduce Lawrence as the European "self", who can easily take control of King Faisal's action, considered as the oriental other. On the other hand, the film makes it clear that Faisal's ambition for the throne arises from his greediness for royalty and power and not for his sense of nationalism (3: 34': 28").

\subsubsection{Dignified Images of the Westerners}

In Lawrence of Arabia (1962), Lawrence is represented as a rational, humane and superior figure among the irrational and inferior oriental "other". For instance, in one scene of the movie, the Arabs were at the verge of starting a violent bloodshed, while Lawrence stopped and prevented it (01: 40': 55"). Lawrence gained the trust of irrational Arabs through the fluent Arabic he spoke and his knowledge of the Arabs' culture when traveling, living, and working among the "Bedouins". Being intimate with the Arabs, Lawrence can analyze their attitudes and guide them so as to make use of them to his own benefits. Thus, media, whether in written texts, like Lawrence in Arabia (2013), or movies, like Lawrence of Arabia (1962), represents the images and tales to its owners' benefits and such distortions of the truth affect the minds of those who are in contact with the discourses and images. Accordingly, the written texts about Lawrence, shows him and the colonizer, as active and the East, as passive. The following excerpt shows how Lawrence plans for the whole region to further the Western interests.

Lawrence was trying to convince Hussein to accept the English and French's deal. Later the king was all but defenseless when ibn-Saud and his Wahhabist warriors finally closed on Mecca in late 1924. Hussein was first taken to exile in Cyprus, before finally joining his son Abdullah in his new capital of Amman, Jordan. The deposed king, who had once dreamt of a pan-Arab nation extending from Mecca to Baghdad, died there in 1931 at the age of seventy-six (Anderson, 2013, p. 1029).

\subsection{Homi Bhabha, Mimicry, and Hybridity in the Movie 1.6.1 The representation of the Arabs}

In Lawrence of Arabia (1962), just like the novel, both the colonizer and the colonized imitate each other. In this section of the thesis, it has been endeavored to give some examples of both these kinds of mimicry from the movie and explain their effects on the individuals. Since Lawrence is a Western character among the Arabs, helping them with war affairs, the current study will first focus on the effects of these phenomena on the Arabs and then will elaborate on Lawrence, as the agent of the West.

The most fundamental instance of such mimicry by the Arabs happens in the train scene when the Arabs and Lawrence loot the train and try to use the stuff they get from it. The Arabs, in this scene, get to learn how to use the different stuff in the train by listening to Lawrence's instructions. One of the Arabs picks up an umbrella, not knowing exactly what it is, and starts dancing with it; other Arabs also look at these products as if they are from another planet (02: 27': 59"). In this way, they need to imitate the colonizer in using these kinds of war stuff and strategies. At the same time, it reinforces the idea of the colonized people as primitive and unaware.

However, as the number of scenes describing the Westerners imitating the Arabs is far more than those describing the Arabs imitating the Westerners, one may conclude that the effect can be of greater dimensions on the side of the colonizers, compared to the colonized since they are going to attract the colonized's trust and penetrate their society.

The Arabs during the first two decades of the twentieth century have experienced a series of wars, religious conflict, and brutal dictatorships and exploitation (Césaire, 2001, p. 19). However, in reply to such disasters caused by the West, the Arabs are supposed to appreciate West's colonization which offers them a self-governing country, dependent on the powerful countries.

\subsubsection{The representation of the Westerners}

The westerners, and actually Lawrence as their agent, also imitated the Arabs in different ways. In this section, the focus will be on the main Western character, Lawrence. This character imitates Arab culture in different ways. One of the most important instances of this mimicry is in the way of his wearing clothes, which was already discussed in the previous sections. The first time that Lawrence wore an Arabic costume was also significant. In this scene and after he gets dressed, he parades around the scene, as if trying to imitate the Arabs and getting accustomed to the new traditions (1:20': 35").

Another scene of the movie presents Lawrence as trying to copy Arabic greeting, saying "salam" (meaning "hello" in Arabic language) (1:21': 15"), even while the movie is all in English. As already mentioned, language is considered a weapon in discussing the colonial and postcolonial discourses, so this scene indicates that Lawrence is getting affected by the Arab culture. In one other scene of the movie, he tries to eat and behave like the Arabs (1: 31': 20"). Another part of the film depicts Lawrence as riding a camel (01: 01': 14"). It is said that eating, dressing, speaking are all parts of a nation's tradition and culture and they are all imitated by the Western character in the movie. It reveals the fact that the colonizer is also affected by the colonized, even sometimes to a greater extent. 
In the same scene, another instance of such mimicry and hybridity at the same time happens, when Lawrence is depicted as dressed partly in a Western uniform and partly in an Arabic headdress (see figure 5 in Appendix). In this scene, we can easily understand the hybridization of the two cultures. Now, he is getting away from the Western identity that he once used to have (01: 01': 14"). This shows how the two cultures are mixed up together as a result of colonization.

The main communicative strategy between humans is language and it affects their lives and social practices in various ways. The political beliefs, for instance, are mainly affected by the language of the news and ideas whether in written or spoken forms. From this critical significance of language usage, it is important to analyze the language and its effect on the social lives of its recipients. Anderson adopts the English language values since in his work English is the only appropriate language and other languages are considered alien. All texts written about the revolt, including Lawrence in Arabia (2013), are gathered by the West and accordingly are based on Western sources. This part from the novel can be the evidence to such a claim. "On a language-related matter, Arabic names can be transliterated in a wide variety of ways. I have adopted the spellings that appear most often in quoted material" (Anderson, 2013, p. 13).

For over a century, films have dramatized fantasy. Since the commencement of movie industry, the Arabs were and still are presented as uncivilized characters. The role of the protagonist is always given to the Western white men who are encountered by filthy Arabs. The white Western hero in this case is Lawrence. The Western media is in charge of instilling the Western audience with one-sided and partial stereotypes about the Arabs and Muslims.

\subsection{Concluding Remarks}

This chapter discussed the false representation of Arabs in Western media in general and in two particular cultural products, the novel and the movie. Moreover, how the book is inspired by the events delineated in the motion picture was another issue that was discussed in this chapter. Scott Anderson and David Lean dehumanize the colonized, i.e. the Arabs, by distorting their images. How media utilizes persuasion as a tactic in affecting its viewers and accordingly controlling them was also elaborated. Moreover, discourse plays a vital role in the production and reproduction of racism. Social knowledge and mental images shape the mind frames of the public. The colonizer and the colonized have been put in many clashes and conflicts. The binary power of the West and the East is also displayed by media. This chapter examined the ways in which Western people write and talk about Easterners to discuss their own superiority. Through powerful discourse of textual illustration and visual images, certain pictures of Arabs as barbaric, exotic, and backward are presented. In doing so, the different strategies stereotyping the Arabs as inferior, such as generalization and repetition, are used in both the movie and the book. Hence, the movie's influence on the book is traced through these similarities.

\section{References}

Abdullah, F. (2013). Mass media discourse: A critical analysis research agenda. Pertanika, 1, 1-16.

Adas, M. (2010). Dominance by design: Technological imperatives and America's civilizing mission. Boston: Harvard University Press.

Alkabani, F. (2016). The meanings of oriental masquerade in T. E. Lawrence's Arabian ventures. British Journal of Middle Eastern Studies, 44(1), 110-129.

Anderson, S. (2013). Lawrence in Arabia: War, deceit, imperial folly and the making of the modern Middle East. Retrieved from iBooks (Mobipocket ebook format).

Anghie, A. (2007). Imperialism, sovereignty and the making of international law. Cambridge: Cambridge University Press

Ashcroft, B., Griffiths, G., and Tiffin, H. (2002). The empire writes back: Theory and practice in post-colonial literatures. New York: Routledge.

Ashcroft, B., Griffiths, G., and Tiffin, H. (2013). Post-colonial studies: The key concepts. New York: Routledge.

Barbudo, M. I. (2014). Lawrence of Arabia (1962): A tragic hero in an ever-lasting quest. Revista Anglo Saxonica, 7(3), 75-87.

Benveniste, E. (1971). Subjectivity in language. Problems in General Linguistics, 1, 223-230.

Bhabha, H. (1983). The other question Homi Bhabha reconsiders the stereotype and colonial discourse. Screen, $24(6), 18-36$.

Bhabha, H. (1994). The location of culture. London and New York: Routledge.

Césaire, A. (2001). Discourse on colonialism. New York: NYU Press.

Eltantawy, V. M. (2007). U.S. newspaper representation of Muslim and Arab women post 9/11 (Doctoral dissertation). Available from Georgia State University database https://scholarworks.gsu.edu/cgi/viewcontent.cgi?referer=https://scholar.google.com/andhttpsredir=1 andarti cle $=1017$ andcontext $=$ communication_diss.

Foucault, M. (1980). Power/knowledge: Selected interviews and other writings, 1972-1977. New York: Pantheon. 
Foucault, M. (2003). Madness and civilization. New York: Routledge.

Foucault, M. (2012). Discipline and punish: The birth of the prison. New York: Vintage.

Fraiman, B. (2017). Lawrence of Arabia is a glorious 4-hour piece of filmmaking history [Blog post]. Retrieved from https://cinephiliabeyond.org/lawrence-arabia-glorious-4-hour-piece-filmmaking-history/

Fraiman, S. (1995). Jane Austen and Edward Said: gender, culture, and imperialism. Critical Inquiry, 21(4), 805821.

Hewett, M. A. (2004). Michel Foucault: Power/knowledge and epistemological prescriptions (Master's thesis). Available from University of Richmond database https://pdfs.semanticsc holar.org/ 10ca/f85e63202bd4d c098e0dcd38fa365aa504e0.pdf.

Ifversen, J. (2003). Text, discourse, concept: Approaches to textual analysis. Kontur, 7, 60-69.

Lawrence, T. E. (1926). Seven pillars of wisdom: a triumph. Cape.

McQuail, D. (1994). Mass communication theory: An introduction. New York: Routledge.

Memmi, A. (1974). The colonizer and the colonized. (H. Greenfeld, Trans.). Boston: Beacon.

Merten, K., and Krämer, L. (2016). Postcolonial studies meets media studies: A critical encounter. Germany: Transcript Verlag.

Mills, S. (2003). Michel Foucault: Routledge critical thinkers. New York: Routledge.

Mills, S. (2004). Discourse. New York: Routledge.

Muharram, M. A. H. (2012). The marginalization of Arabic fiction in the postcolonial and world English curriculum: Slips? or Orientalism and racism?. The Minnesota Review, 78, 130-145.

Ridouani, D. (2011). The representation of Arabs and Muslims in western media. RUTA Comunicación.Retrievedfromhttp://ddd.uab.cat/pub/ruta/20130740n3/20130740n3a7.Pdf.

Said, E. (1978). Orientalism. New York: Routledge.

Said, E. (2001). Power, politics, and culture. New York: Vintage.

Said, E. (1993). Culture and imperialism. New York: Vintage.

Said, E. W. (1983). The world, the text, and the critic. Boston: Harvard University Press.

Said, E. W. (1985). Orientalism reconsidered. Race and class, 27(2), 1-15.

Shaheen, J. G. (1984). The TV Arab. Ohio: Bowling Green State University Popular Press.

Sium, A., Desai, C., and Ritskes, E. (2012). Towards the tangible unknown: Decolonization and the indigenous future. Decolonization: Indigeneity, Education and Society, 1, 1-13.

Sykes, C. (2016). The man who created the Middle East a story of empire, conflict and the Sykes-Picot agreement. Paris: William Collins.

Wilmington, M. (2002). Lawrence in Arabia. In J. Carr (Ed.), The A list: The National Society of Film Critics' 100 essential films, pp.1-2. Cambridge: Da Capo Press.

Wilson, J. (1990). Lawrence of Arabia: The authorized biography of T.E Lawrence. New York: Atheneum. 